\title{
Bombed Archaeology: Towards a Precise Identification and a Safe Management of WWII's Dangerous Unexploded Bombs
}

\section{Pier Matteo Barone}

Archaeology and Classics Program, American University of Rome, Via Pietro Roselli 4, 00153 Rome, Italy; p.barone@aur.edu

Received: 12 August 2019; Accepted: 23 September 2019; Published: 24 September 2019

\begin{abstract}
The massive bombings during World War II (WWII) have had a lasting impact across the Italian landscape. The problem of dangerous unexploded bombs is particularly relevant since the bombsites are buried beneath the soil close to inhabited and/or touristic areas. Archaeological sites, such as Pompeii and Vulci, were heavily bombed, and nowadays, archaeologists excavate these bombs during their digs. Thus, there is a real risk to people's safety. While the aerial photo collection is a powerful record of the landscapes of wartime Italy, plotting buried unexploded bomb hazard maps remains important in identifying their precise location in the modern landscape. Ground penetrating radar (GPR) - a non-destructive technique (NDT) — can help detect these bombs buried beneath the soil by providing an accurate horizontal and vertical position. Using aerial photos and NDTs, such as GPR, this future project explores the WWII human experience to preserve and manage the safety of both the archaeological heritage and involved users by using the data to create an open-access WebGIS platform.
\end{abstract}

Keywords: UXB; GPR; archaeology; GIS; NDT

\section{Introduction}

Using techniques developed by the British Royal Air Force, the WWII aerial reconnaissance provided the photo information needed to identify targets, plan attacks, and assess bombing damage [1-6]. However, it is difficult to calculate the number of bombs dropped on Italy. During WWII, pilots were trained to carpet bomb, which encompassed more than 12 million acres of land, leaving behind crater-scarred landscapes across the country. Post-war estimates suggest that $10-15 \%$ of the aerial bombs used failed to detonate as intended, so these areas are currently contaminated by a large number of dangerous unexploded bombs that remain under the surface $[4,5]$. These detonator malfunctions can be estimated as 37,900 tons of unexploded aircraft bombs in Italy, roughly 80,000-100,000 devices of various tonnages and types $[7,8]$.

Experts in this particular field informally estimate that the findings made between 1945 and today add up to about $60 \%$ of the total unexploded; on the basis of the approximate aforementioned numbers, it is possible to assume that there are still about 15,160 tons of unexploded air bombs $( \pm 30,000$ to 40,000 devices). However, according to data from the Ministry of Defence, 60,000 bombs are found every year in Italy, most of which date back to WWII. These numbers destroy the reliability of these counts and highlight the problem in a macroscopic way, making it clear that there is a need to address the UXB (unexploded bomb) problem more methodically, especially at the national level $[1,4,5]$.

Given the uncertainty about the total number of unexploded bombs in Italy as of 1945, it is difficult to correctly assess the number or percentage of unexploded aerial bombs still present today on Italian territory; in fact, the figures recurring in literature are very divergent $[9,10]$. However, explosives 
degrade very slowly and remain active for hundreds of years; the deterioration of the mechanical parts sometimes makes them even more sensitive and, therefore, more dangerous as evidenced by the 11 wounded with serious disabilities in 2013 alone and the three deaths in the last few years [8]. Further, those who work on construction sites know that this is a real risk. The problem of reclamation is very complex and, above all, very expensive, even when the final result is negative, i.e., there is no device $[4,5,10]$. The actual reclamation takes place following the accidental discovery of UXB during the execution of work not preceded by specific preventive analysis or following its discovery during the execution of operations aimed at excluding the presence in advance in the area affected by works. Current Italian legislation in force [10] establishes the responsibility of those who work on-site with regards to the identification of the security threat on the one hand and the exclusive competence of the Ministry of Defence with regards to the coordination and execution of the reclamation, whether direct or contracted to companies specializing in the reclamation of minefields [11], on the other hand.

In this context, a case with peculiar characteristics is presented by the presumable survival of war remnants and/or unexploded bombs in archaeological areas [12,13]. Archaeologists have often come across this problem; for example, the war preparations found in the 80s in the excavation of the Roman villa of Settefinestre [14], or the ammunition found in the 90s hidden in the ruins of Portus [15,16], which are believed to be the work of partisan groups.

However, there are two emblematic cases close to very important Italian archaeological areas: Pompeii (NA) and Vulci (VT). The area of Pompeii was bombed by the Allied Air Force on several occasions during military operations in preparation for the conquest of Naples (which occurred on 1 October 1943) - there were at least nine incursions between 24 August and 20 September 1943, with other minor ones between 21 and 26 September (REPORT, 1946). The area between Vulci and Montalto di Castro was attacked with 108 bombs of various kinds on 22 February 1944, starting at 12:12 pm, to destroy the crucial railway network of Central Italy [17]. Figure 1 shows the geographical position of these two sites in relation to the advance of the Allied front against the Germans between 1943 and 1944.

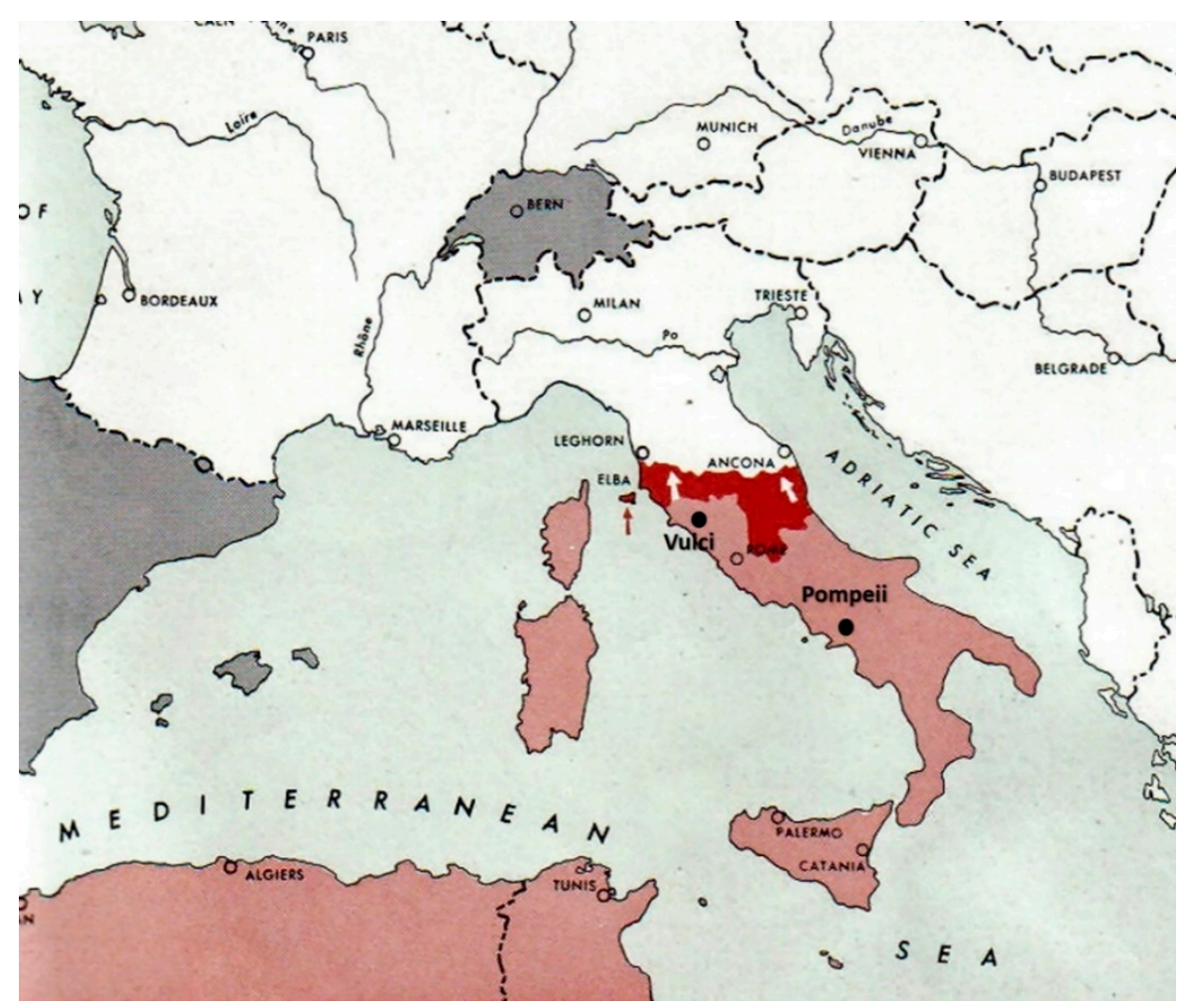

Figure 1. Map of the front against Germany (in red) between 1943 and 1944 when the areas surrounding Pompeii and Vulci were intensely bombed. 
The two aforementioned areas are those on which the study presented in this article would like to focus. If sufficient funds are obtained to carry out the research, the project would not only analyze the subsoil of these two areas and locate possible UXB still buried, but also and above all, create a universally accessible database that is constantly updated and allows both competent authorities and people involved in the protection and conservation of cultural and archaeological heritage to consciously plan research in safety.

Nevertheless, the mere mapping of all the aerially visible bomb craters from the various aerial photos in the archives constitutes a certain basis of knowledge [18]. However, the possibility of using a multi-temporal imagery dataset together with non-destructive techniques (NDTs), such as ground penetrating radar (GPR), can help in better understanding the presence of possible dangerous unexploded bombs in the subsurface [19-21]. Moreover, real-time maps (i.e., maps produced right after the acquisition of the data directly on-site) can be created with a precise location of these hidden bombs close to archaeological and touristic areas, thereby protecting historical knowledge, the Italian territory, and the people who frequent it [22]. These maps, of course, can be periodically updated with emerging data on UXBs as the project progresses. The idea is to use this data in an open-access WebGIS platform to create a risk map and to preserve and manage the safety of both the archaeological heritage and the involved users.

The aim of this project is to use different remote sensors to evaluate the risk of unexploded bombs in two conflicted Italian archaeological landscapes. The combination of WWII aerial photos, modern satellite images, and, differently from other geophysical methods, GPR can help in the following ways: (i) precisely locating the unexploded air-dropped bombs close to the two relevant archaeological sites (Pompeii and Vulci) and (ii) creating a risk map with their location, dimension, and depth through a WebGIS platform.

\section{Methodology}

Until recently, detecting UXBs had been a tedious and expensive process [4-6]. The goal of this project is to locate and map dangerous unexploded bombs close to archaeological areas to prevent risks to people and objects. The goal is divided into the following four main objectives: (1) identifying and mapping general areas of concentrated bomb craters using historical air photos and records, (2) intensely searching these areas on a larger scale using multi-temporal imagery, (3) confirming the presence of individual dangerous unexploded bombs using GPR, and (4) creating an open-access geographical information system (GIS) platform useful for all people involved or interested.

As per the main flow of the research, a specific methodology is necessary to fulfil the objectives (Figure 2) as follows:

(1) Identifying and mapping general areas of concentrated bomb craters using historical air photos and records: The Italian archives of aerial photographs have rich and varied holdings that are a valuable source for the study of the landscape and cultural heritage, especially in the larger parts of the country affected by significant change during the second half of the 20th century. It is worth emphasizing that these holdings include unique imagery from WWII that is not duplicated elsewhere, despite the large numbers of photographs of Italy held in the archives in the UK and USA. These include "post-strike" photographs taken to help assess the success of bombing raids, which highlight the potential importance of this imagery in the writing of history-recording events as they do-alongside ongoing processes and landscapes that have now changed in many ways.

(2) Intensely searching these areas on a larger scale using multi-temporal imagery: As time goes on, aerial photography has evolved from aircraft-borne cameras to digital images taken from satellites. Furthermore, modern aerial photos with increasingly higher resolution will remain relevant research tools. These new satellites carry multispectral sensors that allow images to have multiple bands, which can be used for different spectral analyses. Because of this, the market for the public use of these images ranges widely from base mapping to harder diagnosing. Consequently, accessibility to these images can vary from open access (e.g., Google) to more expensive solutions. 
(3) Confirming the presence of individual dangerous unexploded bombs using GPR: These days, brand-new GPR equipment can help in precisely locating and producing real-time maps of the investigated areas in depth without any interferences such as tourism flows, archaeological investigations, or regular site attendance from the surrounding environment in both Pompeii and Vulci. A 500MHz antennas system with a dedicated software can help precisely detect the dangerous unexploded bombs buried in the subsurface by investigating enough subsoil in depth to obtain a perfect signal penetration-resolution ratio.

(4) Creating an open-access GIS platform useful for all the people involved or interested: A GIS is not only just a powerful spatial analysis tool allowing for a better understanding and evaluation of a territory and its potential but also one of paramount importance in disseminating information at different levels from local to international audiences. Meanwhile, a web-geospatial database (WebGIS) is created from attack reports, images, and reports. Records include precise bomb lists, coordinates of targets, mission descriptions, and results. On the basis of available data, high-quality reconnaissance imagery may be acquired from archives-both digitalized and geocoded-that are chosen in order to cover all locations in the two study areas, and at different dates in cases of repeated attacks on targets. Creating an open-access WebGIS that maps the dangerous unexploded bombs close to relevant Italian archaeological areas will thus allow remote and secure access to maps and data through the internet, not only for safe management of risks but also for the availability of the data from a local to international scale.

It should be noted that Figure 2 contains real reported data acquired near the entrance of the archaeological site of Pompeii, which represent the embryonic phase of this research and from which the proposal itself presented here takes its cue. The aerial photo on the left shows the intense bombing action that took place during WWII. In the center, a recent satellite photo of the same point highlights the presence of intense urbanization work a few steps from the entrance of one of the most famous Italian archaeological sites. Finally, on the right, using schematics, the functioning of the GPR locating buried UXBs is reported by using a real radargram acquired in that area that clearly identifies a UXB later brought to light [23].
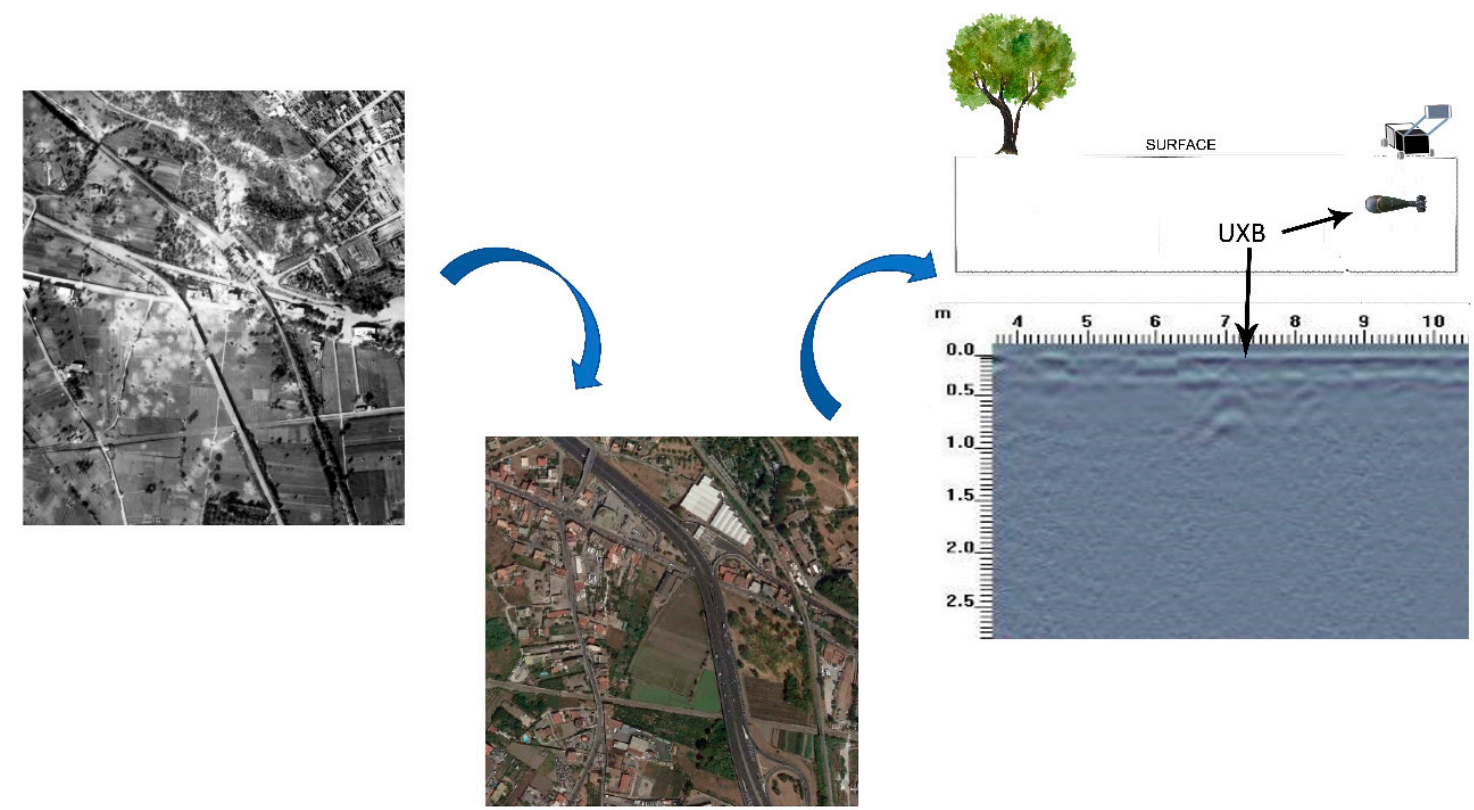

Figure 2. A schematic representation of the data acquisition of the project: from the left, the comparison between a real WWII aerial image of the entrance at the archaeological site of Pompeii and the equivalent modern satellite image (in the middle) to focus on a real GPR research finding, the buried UXB (on the right). 


\section{Discussion and Potential Results}

This project proposes a more cost-effective and easier method for locating dangerous unexploded bombs than the intense ground methods and complex programming computer-based methods that have previously been used to locate possible dangerous unexploded bombs [18-24].

Moreover, this is the first time in which this methodological approach involves archaeological areas while taking into account the risks for tourism, archaeological works, and regular people. Throughout the testing process in the two Italian archaeological sites, multiple methods of location will be performed with varying levels of success based on the available imagery. This method will hopefully be applied to study areas around the world and ultimately help save lives. For future research, the actual application of these methodologies to archaeological conflict landscapes should improve understanding and security. Therefore, it is crucial to implement all the procedures in a GIS environment in order to estimate risks and identify the characteristics of possibly present bombs available in terms of current geographical coordinates. Archaeological works, construction planning, and civil defense operation can have a huge cost-effectiveness advantage using this shared information through a web catalogue.

This remote sensing approach for the evaluation of risks close to densely frequented archaeological areas is completely new and will be of paramount importance for mapping the risk of unexploded bombs from WWII in a characteristically Italian archaeological landscape. Nobody has tried to produce a real-time map of these dangerous bombs hidden in the subsoil with precise locations and high-level resolution. The main outcome will be an open-access WebGIS with various information (first of all, a UXB risk map), accessible remotely, and connecting multiple levels of users (from locals to internationals). The following are also added benefits: (i) reducing lead times-a WebGIS offers organizations the tools to quickly import geo-data and present it on a map in multiple formats; (ii) improving cross-collaboration-a WebGIS is one of the easiest ways to improve internal and external communications as teams can work collaboratively to create, edit, publish, and share maps with key project shareholders internally or externally within an organization; (iii) low-cost barrier to entry-a WebGIS is developed on opensource principles. If a change to a business process occurs, a WebGIS can evolve with the business with minimal development costs and quick deliverables. In addition, the organization can change suppliers quickly and easily due to their data being hosted on the cloud; (iv) connecting multiple structured data sources-a WebGIS provides businesses with the tools to create insights and predictive modelling to support policy-making by connecting to data from third-party web map services (WMS), which can then be revoked with a few simple clicks from within the account settings dashboard. Connecting to third-party WMS requires no custom development and the administrator can create this connection without any technical expertise; (v) supporting real-time spatial analysis-structured data can be supplemented with unstructured sources from various resources; (vi) access to web maps from any device remotely-a WebGIS allows GIS consultants, specialists, and teams to become mobile as web maps are accessible on desktops, tablets, and mobiles as long as mobile data is enabled. This allows administrators and users to interact with, manipulate, and edit data from multiple locations, making them more efficient with their time and reducing lead times of tasks; and (vii) publishing and sharing multi-layer features and points on a single web map-visualizing geo-data on a web map provides data analysts with the tools to import huge amounts of data from multiple sources to provide context to it. Maps can be published publicly without delay and shared socially or embedded onto third-party websites depending on the requirements (Figure 3).

The potential results of this research are of enormous importance both in terms of protecting the safety at work of the people involved in the research and use of these archaeological sites and for the improvement that such research would bring in terms of cultural resource management for the satellite activities. However, the considerable resonance that such a project could have at national and international level in sites with similar problems should also not be overlooked. Further, unique intervention procedures could also be defined in order to maximize positive interventions and minimize costs. 


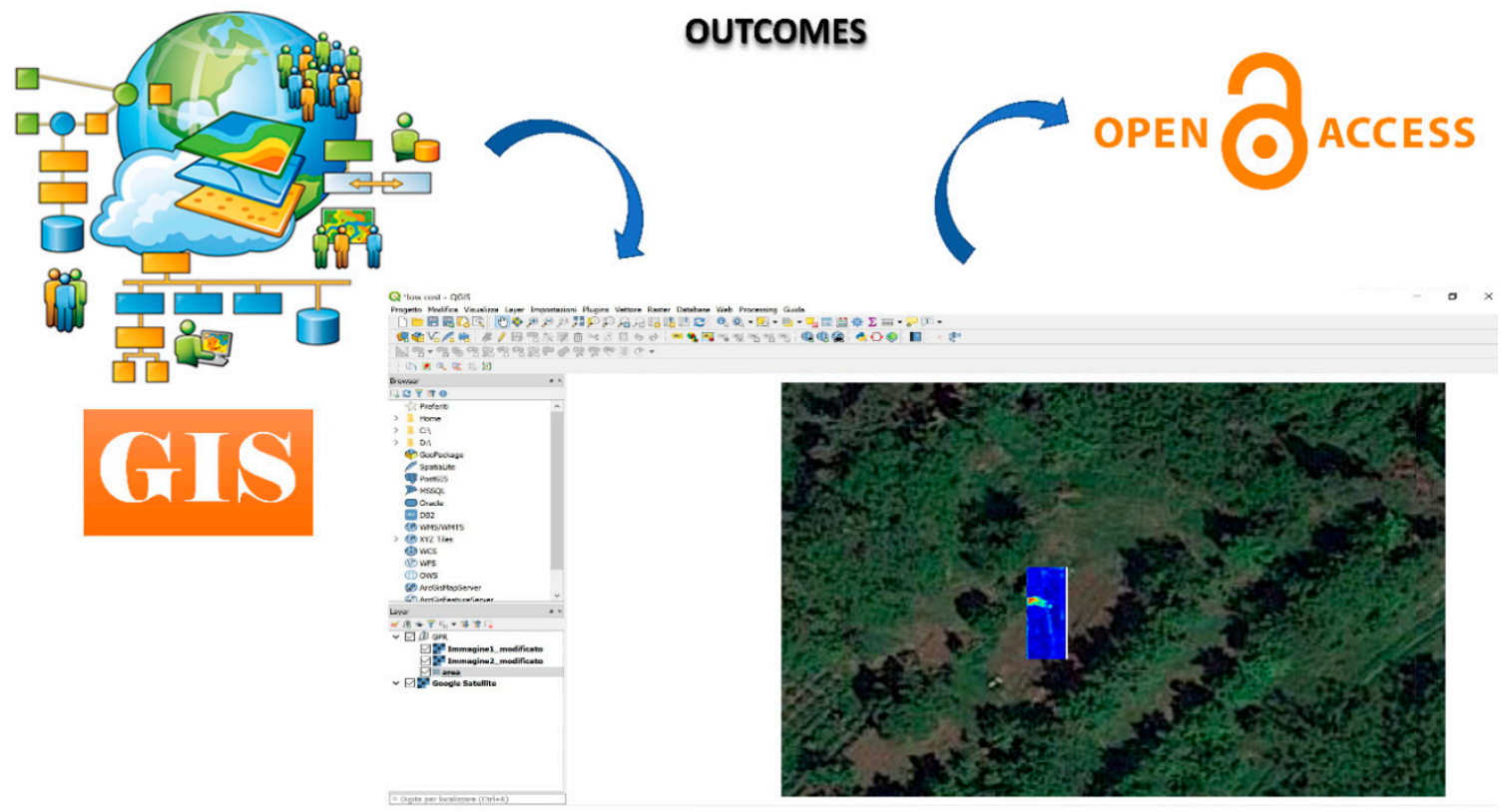

Figure 3. The outcome of the proposed research: using the data acquired, it will create a GIS that can be published online and with open access.

In order to better evaluate this work and the potential results, a list of indicators was prepared to monitor progress toward the research goals (Figure 4). The criteria followed by these indicators are data record, public engagement, science education, open access, and governance. Through these criteria, it is possible to monitor not only the performance indicators (divided into process and outcome indicators) but also perception indicators.

\begin{tabular}{|c|c|c|c|}
\hline \multirow{2}{*}{ Criteria } & \multicolumn{2}{|c|}{ Performance indicators } & \multirow{2}{*}{ Perception indicators } \\
\hline & Process indicators & Outcome indicators & \\
\hline Data record & $\begin{array}{l}\text { Percentage achievements documented by specific } \\
\text { actions and on-site surveys }\end{array}$ & $\begin{array}{l}\text { Percentage of dangerous unexploded bombs found by all the } \\
\text { remote sensors }\end{array}$ & \\
\hline $\begin{array}{l}\text { Science } \\
\text { education }\end{array}$ & $\begin{array}{l}\text { Planning various dissemination systems from a local } \\
\text { to international scale }\end{array}$ & $\begin{array}{l}\text { Percentage of disseminated research with at least one } \\
\text { educational resource deliverable }\end{array}$ & \\
\hline Open access & $\begin{array}{l}\text { Inclusion of an open-access WebGIS as the main part } \\
\text { of the research }\end{array}$ & $\begin{array}{l}\text { Percentage of research that reports real added value by an } \\
\text { open science mechanism (for themselves and/or other } \\
\text { actors) through the access }\end{array}$ & $\begin{array}{l}\text { The extent to which members of the public have visited the } \\
\text { project web-environment and found it useful }\end{array}$ \\
\hline
\end{tabular}

Figure 4. The list of indicators to monitor progress toward the research goals.

\section{Conclusions}

The problem of dangerous unexploded bombs is particularly relevant when the bombsites are buried beneath the soil close to inhabited and/or touristic areas. This remote sensing approach for the evaluation of risks close to densely frequented archaeological areas is completely new and will be of paramount importance for mapping the risks of unexploded bombs from WWII in a characteristically Italian archaeological landscape. Given the open-access nature of this research, the practical and effective implications are evident with undoubted social, economic, and cultural benefits. If this project obtains proper funds to be structured and evolve from its embryonic state, it could benefit not only the 
community around the two archaeological sites of Pompeii and Vulci but also other such sites with similar problems.

Funding: This research received no external funding.

Conflicts of Interest: The author declares no conflicts of interest.

\section{References}

1. Shepherd, E.J.; Palazzi, D.S.; Leone, G.; Mavica, M.M.M. La collezione c.d. USAAF dell'Aerofoteca Nazionale. Lavori in corso. Archeol. Aerea 2012, 6, 13-32.

2. Cowley, D.C.; Stichelbaut, B.S. Historic Aerial Photographic Archives for European Archaeology. Eur. J. Archaeol. 2012, 15, 217-236. [CrossRef]

3. Cowley, D.C.; Ferguson, L.; Williams, W. The Aerial Reconnaissance Archives: A Global Aerial Photographic Collection. In Archaeology from Historical Aerial and Satellite Archives; Hanson, W.S., Oltean, I.A., Eds.; Springer: New York, NY, USA, 2016.

4. Baldoli, C.; Knapp, A.; Overy, R. Bombing, States and Peoples in Western Europe, 1940-1945; Continuum: Norfolk, UK, 2011.

5. Shepherd, E.J. Mapping unexploded ordnance in Italy: The role of World War II aerial photographs. In Conflict Landscapes and Archaeology from Above; Stichelbaut, B., Cowley, D., Eds.; Ashgate: Oxfordshire, UK, 2016; pp. 205-217.

6. Cuttini, R. Italian World War I Aerial Photographs for Landscape Study and Public Engagement. In Conflict Landscapes and Archaeology from Above; Stichelbaut, B., Cowley, D., Eds.; Ashgate: Oxfordshire, UK, 2016; pp. 265-278.

7. Office of the Under Secretary of Defense for Acquisition Technology and Logistics. Report of the Defense Science Board Task Force on Unexploded Ordnance; Penny Hill Press: Damascus, MD, USA, 2016; ISBN 978-1530960262.

8. Fornaciari, C.S. La ricerca storica preliminare. Dati, fonti, strumenti per l'analisi e la valutazione del rischio. In Seminario su il Rischio Associato al Rinvenimento di Ordigni Rinvenimento di Ordigni Bellici Inesplosi; CISC: Udine, Italy, 2013.

9. Byholm, B. Remote Sensing of World War II Era Unexploded Bombs Using Object-Based Image Analysis and Multi-Temporal Datasets: A Case Study of the Fort Myers Bombing and Gunnery Range. Master of Science Dissertation, Minnesota State University, Mankato, MN, USA, 2017.

10. Ceraudo, G.; Shepherd, E.J. Italian Aerial Photographic Archives: Holdings and Case Studies. In Landscapes Through the Lens: Aerial Photographs and the Historic Environment; Cowley, D.C., Standring, R.A., Abicht, M.J., Eds.; Occasional Publication of the Aerial Archaeology Research Group No. 2; Oxbow: Oxford, UK, 2010; pp. 237-246.

11. Shepherd, E.J. Le foto aeree della II guerra mondiale conservate in aerofototeca nazionale e il loro potenziale informativo per la sicurezza nazionale. Bollettino di Archeologia Online 2015, 6, 111-130.

12. Finotti, F.; Tonelli, A. Note sull'utilizzo delle foto aeree. In Lo Sguardo Del Sapiente Glaciale. La Ricognizione Aerofotografica Anglo-Americana Sul Trentino (1943-1945); Leoni, D., Marchesoni, P., Eds.; Fondazione Museo Storico Trentino: Trento, Italy, 1997; pp. 72-75.

13. Merler, S.; Furlanello, C.; Jurman, G. Machine Learning on Historic Air Photographs for Mapping Risk of Unexploded Bombs. In Proceedings of the ICIAP-International Conference on Image Analysis and Processing, Cagliari, Italy, 6-8 September 2005; pp. 735-742.

14. Santangeli Valenziani, R. Dallo scavo alle ricostruzioni. Il giardino turrito. In Settefinestre. Una Villa Schiavistica Nell'etruria Romana; Carandini, A., Ed.; Panini Franco Cosimo: Modena, Italy, 1985; pp. 121-128.

15. Bergamo, M. Bombe Sulle Rovine. Bombardamenti Dei Siti Archeologici in Italia Durante la Seconda Guerra Mondiale e Ricostruzioni Postbelliche: Status Quaestionis e Prima Ricognizione Bibliografica; Engramma: Venezia, Italy, 2013.

16. Bergamo, M. Bombe sulle rovine 1943-1944. In Strategia Della Memoria. Architetture e Paesaggi di Guerra; Bergamo, M., Iorio, A., Eds.; Aracnez: Roma, Italy, 2014; pp. 54-63.

17. USSBS. Statistical Appendix to Over-All Report (European War); The United States Strategic Bombing Survey; USSBS: Washington, DC, USA, 1947. 
18. Brenner, S.; Zambanini, S.; Sablatnig, R. Detection of Bomb Craters in WWII Aerial Images. In Proceedings of the OAGM Workshop; Welk, M., Urschler, M., Roth, P.M., Eds.; Verlag der Technischen Universität Graz: Graz, Austria, 2018; pp. 94-97. [CrossRef]

19. Kruse, C.; Rottensteiner, F.; Hoberg, T.; Ziems, M.; Rebke, J.; Heipke, C. Generating Impact Maps from Automatically Detected Bomb Craters in Aerial Wartime Images Using Marked Point Processes. ISPRS Ann. Photogramm. Remote Sens. Spat. Inf. Sci. 2018, 4, 127-134. [CrossRef]

20. Meixner, P.; Eckstein, M. Multi-Temporal Analysis of WWII Reconnaissance Photos. Int. Arch. Photogramm. Remote Sens. Spat. Inf. Sci. ISPRS Arch. 2016, 973-978. [CrossRef]

21. Yarovoy, A. Landmine and Unexploded Ordnance Detection and Classification with Ground Penetrating Radar. In Ground Penetrating Radar: Theory and Applications; Jol, H.M., Ed.; Elsevier: Amsterdam, The Netherlands, 2009; pp. 445-478.

22. Byrnes, J. Unexploded Ordnance Detection and Mitigation; The NATO Science for Peace and Security Program; Springer: Dordrecht, The Netherlands, 2008; ISBN 978-1402092527.

23. Keach, S. Ancient Ruins of Pompeii ‘Hiding 10 Unexploded WW2 Bombs' Dropped During Allied Invasion of Italy. The Sun, 8 July 2019. Available online: https:/www.thesun.co.uk/tech/9460450/pompeii-ww2-bombsallied-invasion-italy/(accessed on 7 September 2019).

24. Barone, P.M. Understanding Buried Anomalies: A Practical Guide to GPR; LAP-Lambert Academic Publishing: Saarbrücken, Germany, 2016; ISBN 978-3659935794.

(C) 2019 by the author. Licensee MDPI, Basel, Switzerland. This article is an open access article distributed under the terms and conditions of the Creative Commons Attribution (CC BY) license (http://creativecommons.org/licenses/by/4.0/). 